\title{
Pengaruh Model Pembelajaran Project Based Learning dan Keterampilan Kolaborasi terhadap Hasil Belajar IPA Siswa
}

\author{
Alamsyah ${ }^{1 *}$, Maman Rumanta ${ }^{2}$, Widiasih ${ }^{3}$. \\ 1 Universitas Terbuka, Serang, Indonesia \\ 2 Universitas Terbuka, Serang, Indonesia \\ 3 Universitas Terbuka, Serang, Indonesia \\ *Corresponding author: alamsyahkebunsayur@gmail.com
}

\begin{abstract}
This research is motivated by the low student learning outcomes caused by the lack of precise learning methods used by teachers in the learning process and the weak collaboration skills of students as capital in learning science. The purpose of this study is to describe the effect of project based learning on learning outcomes in science subjects and to describe differences in science learning outcomes at different levels of student collaboration skills. This research is an experimental study with a pretest-posttest control group design pattern conducted on fourth grade students at SDN Damar District, the research data were obtained using instruments in the form of student learning outcomes test sheets and collaboration skills observation sheets, then the data were analyzed using two tests. way ANOVA. The results show that there is a significant difference in science learning outcomes between students who study using project based learning and students who learn without using project based learning, this is indicated by a significance value of 0.00 , which is smaller than 0.05 . The average learning outcomes of students who have high collaboration skills tend to be greater than the average learning outcomes of students who have low collaboration skills. Based on these data, it can be concluded that the use of project based learning models has an effect on student learning outcomes.
\end{abstract}

Keywords: collaboration skills; project based learning; science learning outcomes

\section{ABSTRAK}

Penelitian ini dilatar belakangi oleh rendahnya hasil belajar siswa yang diakibatkan oleh kurang tepatnya metode pembelajaran yang digunakan oleh guru dalam proses pembelajaran dan lemahnya keterampilan kolaborasi siswa sebagai modal dalam belajar IPA. Tujuan dari penelitian ini adalah mendeskripsikan pengaruh project based learning tehadap hasil belajar pada mata pelajaran IPA dan mendeskripsikan perbedaan hasil belajar IPA pada tingkat keterampilan kolaborasi siswa yang berbeda. Penelitian ini merupakan penelitian eksperimen dengan pola pretest-posttest control group design yang dilakukan pada siswa kelas IV SDN Kecamatan Damar, data hasil penelitian diperloeh dengan menggunakan instrumen berupa lembar tes hasil belajar siswa dan lembar observasi keterampilan kolaborasi, data dianalisis dengan menggunakan uji two way ANOVA. Hasil penelitian menunjukkan bahwa terdapat perbedaan yang signifikan hasil belajar IPA antara siswa yang belajar dengan mengguunakan project based learning dengan siswa yang belajar tanpa menggunakan project based learning. Rata-rata hasil belajar siswa yang memiliki keterampilan kolaborasi tinggi cenderung lebih besar jika dibandingkan dengan rata-rata hasil belajar siswa yang memiliki keterampilan kolaborasi rendah yang dipengaruhi oleh penggunaan model project based learning berpengaruh terhadap hasil belajar siswa.

Kata Kunci: hasil belajar IPA; keterampilan kolaborasi; project based learning

\section{Pendahuluan}

Peningkatan kualitas pendidikan bangsa harus diwujudkan dengan menjadikan suasana belajar dan proses belajar yang baik agar potensi peserta didik berkembang secara maksimal. Denga terciptanya suasana belajar dan proses belajar yang baik dalam pendidikan, maka diharapkan dapat menciptakan mutu dan hasil belajar yang baik pula. Setelah terciptanya mutu dan hasil belajar yang baik selanjutnya berdampak pada terciptanya sumber daya 
manusia yang mumpuni dan berkualitas. Oleh karena itu bisa dikatakan bahwa ujung pangkal proses pendidikan dapat dicermati dari sisi proses pembelajaran. Salah satu mata pelajaran yang termuat dalam kurikulum pendidikan di Indonesia adalah Ilmu Pengetahuan Alam (IPA). IPA merupakan ilmu yang berperan penting dalam memajukan daya pikir manusia dalam memecahkan masalah kehidupan, karena pada obyek dasarnya IPA adalah ilmu yang mempelajari cara mencari tahu tentang alam semesta dan segala isinya secara sistematis. IPA merupakan konsep pembelajaran alam dan mempunyai hubungan yang sangat luas terkait dengan kehidupan manusia. Pembelajaran IPA sangat berperan penting dalam proses pendidikan dan juga perkembangan teknologi. Pembelajaran IPA diharapkan bisa menjadi wahana bagi siswa untuk mempelajari diri sendiri dan alam sekitar, serta pengembangan lebih lanjut dalam penerapan dalam kehidupan sehari-hari (Surahman, Paudi, \& Tureni, 2015). IPA bukan hanya sekedar menghafalkan konsep dan prinsip IPA melainkan, dengan pembelajaran IPA diharapkan siswa dapat memiliki sikap dan kemampuan yang berguna bagi dirinya dalam memahami perubahan yang terjadi dilingkungannya dan berprestasi dalam pelajaran IPA (Khairudin \& Soedjono, 2015). Pembelajaran IPA di Sekolah Dasar merupakan pondasi awal dalam menciptakan siswa-siswa yang memiliki pengetahuan, keterampilan dan sikap ilmiah (Tursinawati, 2013). Pandangan tersebut mengarah pada makna bahwa pembelajaran IPA di SD hendaknya bertujuan untuk memberikan dasar yang kuat bagi siswa untuk menanamkan wawasan dan sikap ilmiah siswa agar kelak bisa dimanfaatkan dalam menghadapi dan memecahkan permasalahan dalam kehidupan sehari-hari dan menerima perubahan yang terjadi di lingkungannya, dengan demikian pembelajaran IPA di sekolah harus mampu mengantarkan siswa pada pengalaman belajar yang lebih dari sekedar menghafal konsep dan teori. Pernyataan tersebut sejalan dengan tujuan pendidikan abad 21 yakni melakukan penekanan terhadap kreativitas, pemikiran kritis, pemecahan masalah, dan komunikasi (Purnomo, Mahpudin, \& Sunanto, 2020). Namun demikian permasalahan dalam pembelajaran IPA kerap menjadi tantangan dalam melakukan pencapaian tujuan pembelajaran tersebut. Permasalahan yang umumnya muncul dalam dunia pendidikan di Indonesia adalah lemahnya proses pembelajaran, proses pembelajaran yang lebih sering diarahkan pada aktifitas hafalan kurang mampu mendorong siswa dalam mengembangkan kemampuan berpikir kritis dan sistematis sehingga hasil yang didapat siswa tidak mampu menerapkan konsep-konsep yang dipelajari dalam memecahkan permasalahan di kehidupan sehari-hari (Tias, 2017). Materi pelajaran IPA yang padat dan tuntutan untuk menghapal materi menjadikan IPA sebagai salah satu mata pelajaran yang kurang diminati oleh siswa kelas IV SDN Damar. Berdasarkan study pendahuluan yang dilakukan pada kelas IV SDN Damar, hasil belajar siswa pada mata pelajaran IPA di sekolah ini masih tergolong rendah. Penggunaan model project based learning bisa menjadi alternatif dalam mengatasi permasalahan pendidikan khususnya permasalahan pembelajaran IPA di kelas IV SDN Damar.

Hasil belajar adalah kemampuan- kemampuan yang telah dimiliki oleh siswa setelah ia mengalami proses belajarnya (Sudjana, 2005). IPA atau sains adalah suatu kumpulan teori yang sistematis, penerapannya secara umum terbatas pada gejala-gejala alam, lahir dan berkembang melalui metode ilmiah seperti observasi dan eksperimen serta menunjukkan sikap ilmiah seperti rasa ingin tahu, terbuka, jujur, dan sebagainya (Trianto, 2014). Pembelajaran sains merupakan pembelajaran berdasarkan pada prinsip-prinsip, proses yang 
dapat menumbuhkan sikap ilmiah peserta didik terhadap konsep-konsep IPA (Susanto, 2012). Berdasarkan uraian yang telah dijabarkan, dapat disimpulkan bahwa pembelajaran ipa tidak lain adalah membimbing dan melatih peserta didik untuk mempelajari gejala alamiah dengan melakukan penyelidikan melalui metode atau proses ilmiah serta sikap ilmiah untuk mendapatkan bukti dan penjelasan logika sebagai produk ilmiah serta aplikasinya termasuk interaksinya dengan teknologi dan masyarakat yang dilaksanakan secara terpadu dan utuh dengan tujuan menumbuhkembangkan kompetensi peserta didik pada ranah sikap, pengetahuan, dan ketrampilan. Peserta didik didorong untuk mengostruksi pengetahuannya sehingga pembelajaran lebih bermakna. Keterampilan abad ke-21 mengarah pada tuntutan pengembangan 4C, yakni Communication, Collaboration, Critical Thinking and Problem Solving, dan Creativity and Innovation (Beers, 2011). Pendidikan dituntut untuk dapat menumbuhkan dan mengembangkan semua keterampilan tersebut. Kolaborasi telah diterima sebagai keterampilan yang penting untuk mencapai hasil-hasil belajar maupun pekerjaan yang efektif dan bermakna. Menurut Trilling, 2009 kompetensi Collaboration Skill meliputi menunjukkan kemampuan untuk bekerja secara efektif dan menghormati perbedaan kelompok, berlatih untuk memiliki fleksibilitas dan kemauan berkompromi yang diperlukan untuk mencapai tujuan bersama dan berasumsi bahwa tugas kolaboratif merupakan tanggung jawab bersama dan menghargai kontribusi individu oleh setiap anggota tim. Keterampilan kolaborasi yang baik didukung dengan penggunaan model pembelajaran yang baik dapat memberikan dampak positif terhadap hasil belajar siswa pada mata pelajaran IPA. Selain itu menurut Miharja, Rumanta, \& Rahayu (2021: 56) pembelajaran akan berhasil manakala peserta didik memiliki motivasi yang baik dalam pembelajaran sehingga akan berimplikasi teradap hasil belajarnya.

Model pembelajaran merupakan kerangka konseptual yang melukiskan prosedur pembelajaran secara sistematis dalam mengelola pengalaman belajar peserta didik agar tujuan belajar tertentu yang diinginkan dapat tercapai (Suprihatiningrum \& Jamil, 2016). Project based learning adalah model pembelajaran yang menggunakan proyek/kegiatan sebagai media yang digunakan pada permasalahan komplek yang diperlukan peserta didik dalam melakukan investigasi dan memahaminya (Kurniasih, 2014). Dengan pembelajaran berbasis proyek, peserta didik mendapat tambahan keuntungan di luar yang diharapkan berupa: a) Peserta didik dapat membangun ketrampilan komunikasi dan menghilangkan batas-batas kultural serta memperoleh sebuah consensus; b)Peserta didik dapat membangun keterampilan ikuiri dan menimbulkan sikap ingin tahu pada fenomena sekitar; c) Peserta didik belajar untuk menyesuaikan waktu tugas yang didapat karena peserta didik tahu pekerjaannya berkaitan dengan teman sekelompoknya pada batas waktu tertentu. d) Peserta didik membangun pemahaman yang utuh bagaimana sesuatu terjadi, tidak hanya sebatas di lingkungan sekitar peserta didik; e) Peserta didik akan memperoleh kesan dapat mengubah dunia dengan cara komunikasi yang baik dan memahami teman sekelompoknya. (Boss \& Krauss, 2013).

Terdapat empat komponen pokok dalam pembelajaran berbasis proyek,yakni pertama, Masalah yang bersifat menantang dan memotivasi. PjBL memusatkan perhatian pada sejumlah masalah yang khas, tidak umum, dan bersifat menantang. Masalah ini akan memotivasi peserta didik untuk mengerjakan sebuah proyek yang bermakna dan menghadapkannya pada pengetahuan yang akan diperoleh secara langsung melalui 
aktivitas proyek tersebut. Ke dua, Manajemen kerja. Manajemen kerja merupakan bagian penting dari PjBL, yakni meliputi: 1) Peserta didik membuat perencanaan kerja berupa menentukan sumber informasi, menentukan informasi yang akan dikaji, menyiapkan perangkat yang dibutuhkan dalam penggalian informasi, merancang jadwal kerja; 2) Pengorganisasian kelompok dilakukan dalam bentuk pembagaian tugas dan tanggung jawab; 3) Pelaksanaan proyek sebagai implementasi dari rencana; 4) Evaluasi dan refleksi, dilakukan dalam bentuk menganalisis data yang diperoleh, menginterpretasi, dan menyusun laporan. Ke tiga, Kolaborasi. Aktivitas kolaborasi bermanfaat untuk penyelesaian tugas sesuai jadwal, adanya proses saling berbagi, saling membantu, dan berfungsi efektif dalam meningkatkan kecakapan sosial. Ke empat, Karya akhir. Karya akhir berupa laporan merupakan output dari aktivitas proyek dan juga materi presentasi yang kemudian dipresentasikan. (Ratumanan, 2015).

Tujuan dari dilakukannya penelitian ini adalah untuk mendeskripsikan pengaruh penggunaan model pembelajaran project based learning terhadap hasil belajar IPA, sehingga diharapkan hasil penelitian ini bisa bermanfaat untuk guru dan peneliti lain. Untuk guru diharapkan penelitian ini dapat menjadi acuan dalam pelaksanaan kegiatan pembelajaran yang aktif dan mengembangkan potensi peserta didik terutama pada mata pelajaran IPA, untuk peneliti lain diharapkan hasil penelitian ini dapat menjadi acuan untuk melakukan penelitian lebih lanjut dengan konteks pembelajaran yang berbeda dan karakteristik siswa yang berbeda pula.

\section{Metode Penelitian}

Metode yang digunakan dalam penelitian ini adalah penelitian Experimental dengan pola Pretest-Posttest Control Group Design. Penelitian ini dilakukan dengan desain penelitian faktorial $2 \times 2$.

Desain faktorial $2 \times 2$ digunakan apabila ada dua atau lebih variabel dengan masingmasing variabel memiliki lebih dari satu situasi. Adapun dalam penelitian ini pengelompokan data dibedakan melalui dua perlakuan yaitu model project-based learning dan keterampilan kolaborasi siswa yang disebut faktor atau main effect dan perbedaan pada tiap treatmen disebut level. Pada penelitian terdapat dua level pada model pembelajaran yaitu (A1) merupakan kelompok belajar dengan menggunakan model project-based learning berbantuan vidio dan (A2) merupakan kelompok siswa yang belajar dengan model project-based learning non-vidio. Faktor keterampilan kolaborasi siswa belajar juga terdapat dua level yaitu siswa yang memiliki keterampilan kolaborasi tinggi (B1) dan siswa yang memiliki keterampilan kolaborasi rendah (B2). Masing-masing varibel terdiri dari dua cara maka desain ini dinamakan 2x2 factorial design

Tabel 1. Desain Penelitian Faktorial 2x2

\begin{tabular}{|c|c|c|c|}
\hline \multirow[b]{2}{*}{$\begin{array}{l}\text { Keterampilan } \\
\text { Kolaborasi } \\
\text { (B) }\end{array}$} & \multicolumn{3}{|c|}{ Model Pembelajaran $(A)$} \\
\hline & $\begin{array}{c}\text { Model Project-Based Learning Berbantuan } \\
\text { Video } \\
\left(\mathrm{A}_{1}\right)\end{array}$ & Model & $\begin{array}{l}\text { Project-Based Learning } \\
\text { Non-Video } \\
\left(\mathrm{A}_{2}\right)\end{array}$ \\
\hline Tinggi $\left(B_{1}\right)$ & $\mathrm{A}_{1} \mathrm{~B}_{1}$ & & $\mathrm{~A}_{2} \mathrm{~B}_{1}$ \\
\hline Rendah $\left(\mathrm{B}_{2}\right)$ & $\mathrm{A}_{1} \mathrm{~B}_{2}$ & & $\mathrm{~A}_{2} \mathrm{~B}_{2}$ \\
\hline
\end{tabular}


Keterangan:

$\mathrm{A}_{1} \quad$ : Kelompok siswa yang diajar dengan menggunakan model project-based learning berbantian video.

$\mathrm{A}_{2} \quad$ : Kelompok siswa yang diajar dengan menggunakan model project-based learning non-video.

$\mathrm{B}_{1} \quad$ : Kelompok siswa yang memiliki keterampilan kolaborasi tinggi.

$\mathrm{B}_{2} \quad$ : Kelompok siswa yang memiliki keterampilan kolaborasi rendah.

$\mathrm{A}_{1} \mathrm{~B}_{1} \quad$ : Kelompok siswa yang belajar dengan menggunakan model project-based learning berbantuan video pembelajaran dengan keterampilan kolaborasi tinggi.

$A_{1} B_{2} \quad$ : Kelompok siswa yang belajar dengan menggunakan model project-based learning berbantuan video pembelajaran dengan keterampilan kolaborasi rendah.

$A_{2} B_{1} \quad$ : Kelompok siswa yang belajar dengan menggunakan pembelajaran project-based learning non-video pembelajaran dengan keterampilan kolaborasi belajar tinggi.

$\mathrm{A}_{2} \mathrm{~B}_{2} \quad$ : Kelompok siswa yang belajar dengan menggunakan pembelajaran project-based learning non-video pembelajran dengan keterampilan kolaborasi rendah.

Penelitian ini dilakukan pada tahun ajaran 2019/2020. Adapun sampel dalam penelitian didapat dengan menggunakan teknik random sampling yang dipilih berdasarkan pertimbangan tertentu berdasarkan ciri-ciri atau sifat tertentu yang sudah diketahui sebelumnya. Berdasarkan teknik sampling yang digunakan, maka ditetapkan bahwa subjek dalam penelitian ini adalah kelas IV SDN Damar.

Subjek penelitian dikelompokkan pada kelas eksperimen dan kelas kontrol. Penelitian quasi eksperimental menggunakan kelompok eksperimen dan kelompok kontrol yang diseleksi tanpa prosedur penempatan acak (Creswell, 2014). Awal mula kedua kelas tersebut diberikan soal pretest untuk mengetahui level awal pengetahuan siswa pada mata leajaran IPA, selanjutnya pada kelas eksperimen siswa diberi perlakuan pembelajaran dengan menggunakan model pembelajaran project based learning sementara pada kelas kontrol siswa diberikan pembelajaran dengan model pembelajaran sebagaimana biasanya tanpa perlakuan khusus. Setelah dilakukan kegiatan pembelajaran di kelas eksperimen dan kelas kontrol, langkah berikutnya adalah memberikan soal posttest untuk melihat hasil belajar siswa setelah dilakukan kegiatan pembelajaran dengan perlakuan yang berbeda pada kedua kelas.

Pengambilan data penelitian dilakukan dengan menggunakan instrumen tes yang dirancang sedemikian rupa yang sudah diuji validasi sebelumnya, sehingga dapat mengukur hasil belajar siswa pada mata pelajaran IPA pokok bahasab sifat-sifat bunyi. Adapun kisi-kisi instrumenya sebagai berikut:

Tabel 2. Kisi-Kisi Instrumen Tes Hasil Belajar

Muatan Pelajaran : IPA

Materi Ajar : Sifat-sifat bunyi dan keterkaitannya dengan indera pendengaran.

Kelas/semester : IV (Empat) / 2 (Dua)

Tahun Pelajaran : : $2020 / 2021$

\begin{tabular}{|c|c|c|c|c|c|}
\hline Kompetensi Dasar & \multicolumn{2}{|l|}{ Materi } & $\begin{array}{c}\text { Level } \\
\text { Kognitif }\end{array}$ & $\begin{array}{l}\text { Nomor } \\
\text { Soal }\end{array}$ & \multirow{3}{*}{$\begin{array}{c}\text { Bentuk } \\
\text { Soal } \\
\text { Pilihan } \\
\text { Ganda }\end{array}$} \\
\hline $\begin{array}{l}\text { 3.6 Menerapkan } \\
\text { sifat-sifat bunyi dan }\end{array}$ & $\begin{array}{l}\text { Mendeskripsikan } \\
\text { dan penyebabnya }\end{array}$ & bunyi & $\mathrm{C} 2, \mathrm{C} 3$, & 1,3 & \\
\hline keterkaitannya & $\begin{array}{l}\text { Mengklasifikasikan } \\
\text { sumber bunyi }\end{array}$ & & $\mathrm{C} 4, \mathrm{C} 2$ & $2,4,6,7$ & \\
\hline
\end{tabular}




\begin{tabular}{|c|c|c|c|}
\hline \multirow[t]{6}{*}{$\begin{array}{l}\text { dengan indera } \\
\text { pendengaran. }\end{array}$} & $\begin{array}{l}\text { Menganalisis fenomena } \\
\text { perambatan bunyi melalui } \\
\text { indera }\end{array}$ & $\begin{array}{l}\mathrm{C} 3, \mathrm{C} 3, \mathrm{C} 2, \\
\mathrm{C} 2, \mathrm{C} 3\end{array}$ & $\begin{array}{c}11,12 \\
13,14,17\end{array}$ \\
\hline & $\begin{array}{l}\text { Menganalisis contoh bunyi } \\
\text { dalam kehidupan sehari } \\
\text { hari }\end{array}$ & $\mathrm{C} 4, \mathrm{C} 2$ & 8,9 \\
\hline & $\begin{array}{lr}\text { Menerapkan } & \text { cara } \\
\text { memelihara } & \text { organ } \\
\text { pendengaran } & \end{array}$ & C3 & 15 \\
\hline & $\begin{array}{l}\text { Menganalisis sifat sifat } \\
\text { bunyi }\end{array}$ & $\begin{array}{l}\mathrm{C} 3, \mathrm{C} 4, \mathrm{C} 3, \\
\mathrm{C} 3, \mathrm{C} 3, \mathrm{C} 1, \\
\mathrm{C} 2\end{array}$ & $\begin{array}{l}16,18,20 \\
21,22,23, \\
24\end{array}$ \\
\hline & Media perambatan bunyi & $\mathrm{C} 4$ & 19 \\
\hline & Peredaman bunyi & C5 & 25 \\
\hline
\end{tabular}

Seluruh data yang telah terkumpul dianalisa dengan teknik analisis deskriptif inferensial. Analisis data inferensial membantu peneliti yang memiliki subyek terbatas yaitu terdiri dari uji normalitas, uji homogenitas, dan uji hipotesis. Uji hipotesis digunakan untuk mengungkap pengaruh penggunaan model project based learning terhadap hasil belajar siswa, uji hipotesis ini menggunakan uji statistik two way ANOVA dengan program computer SPSS 23.

\section{Hasil dan Pembahasan}

Data yang diperoleh sebagai hasil penelitian adalah berupa data hasil belajar siswa baik pada kelas eksperimen maupun kelas kontrol. Untuk menganalisi hipotesis penelitian tersebut digunakan uji two way ANOVA dengan aplikasi SPSS. Sebelum melakukan uji two way ANOVA maka diperlukan uji prayarat penelitin yaitu uji normalitas dan uji homogenitas.

Uji normalitas digunakan untuk mengetahui bagaimana persebaran data penelitian yang diperoleh.

Tabel 3. Uji Normalitas

\begin{tabular}{lllllll}
\hline & \multicolumn{3}{c}{ Kolmogorov-Smirnov } & \multicolumn{3}{c}{ Shapiro-Wilk } \\
& Statistic & df & Sig. & \multicolumn{2}{c}{$\begin{array}{l}\text { Statisti } \\
\text { c Df }\end{array}$} & Sig. \\
& & & & c & & \\
\hline $\begin{array}{l}\text { Standardized } \\
\text { Residual for Hasil }\end{array}$ & 0,084 & 82 & $0,200^{*}$ & 0,943 & 82 & 0,001 \\
\hline
\end{tabular}

Hipotesis dalam uji normalitas yaitu apabila nilai sig $>0.05$ maka persebaran nilai terdistribusi normal, namun apabila nilai sig. $<0.05$ maka persebaran tidak terdistribusi normal. Setelah dilakukan analisis hipotesis berdasarkan SPSS maka diperoleh hasil uji normalitas dengan nilai signifikansi sebesar 0.200 , dan nilai sig $>0.005$ sehingga dikatakan terdistribusi normal.

Setelah dilakukan uji normalitas, berikutnya dilakukan uji homogenitas yang berfungsi untuk mengetahui apakah data penelitian bersifat homogen atau tidak.

Tabel 4. Uji Homogenitas

\begin{tabular}{crrr}
\hline $\mathrm{F}$ & $\mathrm{df1}$ & $\mathrm{df2}$ & Sig. \\
\hline, 177 & 3 & 78 &, 912 \\
\hline
\end{tabular}


Setelah dilakukan uji data penelitian menggunakan SPSS diperoleh nilai sig sebesar 0.912 . Dalam hal ini hipotesis menyatakan bahwa apabila nilai sig $>0.05$ maka data penelitian bersifat homogen. Mengenai uji prasyarat penelitian ini telah terpenuhi yaitu data terdistribusi normal dan besifat homogen, sehingga data penelitian dapat dilanjutkan melakukan uji two way ANOVA untuk mengetahui interaksi antar variabel yang diteliti.

Setelah dilakukan uji prasyarat yaitu uji normalitas dan homogenitas terhadap data hasil penelitian, tahapan berikutnya adalah dilakukan analisis perbedaan rata-rata antara hasil belajar siswa kelas eksperimen dan siswa kelas kontrol. Rata rata perbedaan kedua hasil belajar siswa dianalisis dengan menggunakan uji two way ANOVA.

Tabel 5. Deskripsi Hasil Belajar Siswa Kelas Eksperimen dan Kelas Kontrol

\begin{tabular}{|c|c|c|c|c|}
\hline Model & Mean & Std. & \multicolumn{2}{|c|}{ 95\% Confidence Interval } \\
\hline \multirow{2}{*}{ Pembelajaran } & & Error & Lower & Upper \\
\hline & & & Bound & Bound \\
\hline PBL & 83,765 & 1,236 & 81,304 & 86,225 \\
\hline Konvensional & 76,758 & 1,181 & 74,408 & 79,109 \\
\hline
\end{tabular}

Tabel di atas menunjukkan mean atau rata-rata hasil belajar peserta didik yang telah dianalisis menggunakan SPSS windows 23. Dapat dilihat pada kolom mean, disana terdapat hasil belajar peserta didik yang telah diberikan perlakukan dengan project based learning sebesar 83.765. sedangkan hasil belajar siswa kelas eksperimen yang diberi perlakuan dengan model pembelajaran konvensional diperoleh nilai sebesar 76.758. Hal tersebut menunjukan arti bahwa hasil belajar peserta didik setelah diberikan perlakuan dengan project based learning lebih besar daripada hasil belajar peserta didik yang tidak menggunakan model project based learning.

Berikut distribusi masing-masing nilai disetiap peserta didik baik pada kelas eksperimen dan kelas kontrol

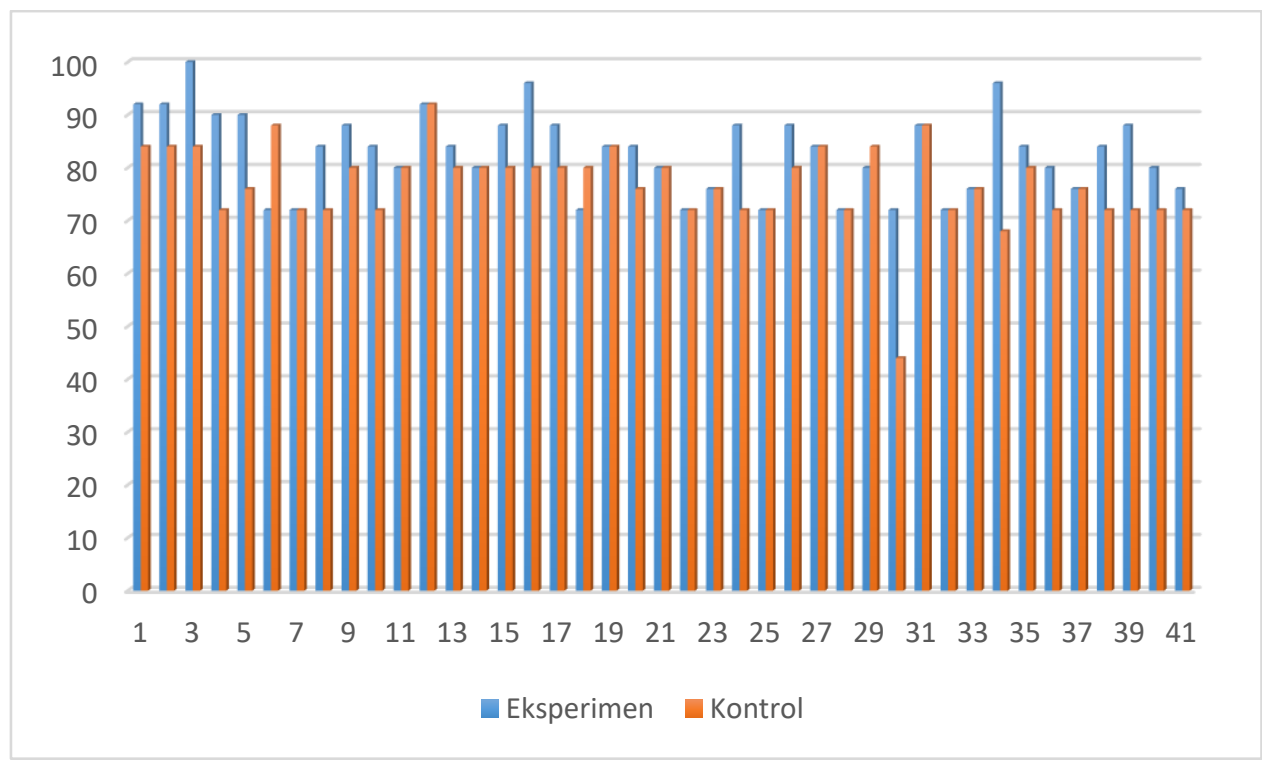

Gambar 1. Distribusi Hasil Belajar Tiap Siswa 
Pada grafik tersebut dapat diketahui terdapat perbedaan yang signifikan antara kedua grafik. Rata-rata nilai siswa kelas eksperimen berkisar dari 75-100. Nilai terendah diperoleh dengan skor 75 dan nilai tertinggi diperoleh oleh siswa dengan skor 100. Kemudian nilai rata rata siswa kelas kontrol yaitu berkisar antara 45-70. Sehingga skor tertinggi pada kelas kontrol yaitu 70, dan nilai terendah yaitu 45 . Hasil perhitungan dengan menggunakan anova dua jalur menunjukkan nilai signifikansi sebesar 0,000 yang mana nilai signifikansi tersebut lebih kecil dari 0,05 yang artinya terdapat perbedaan rata-rata hasil belajar siswa antara siswa yang belajar dengan menggunakan model project-based learning dengan siswa yang belajar dengan pembelajaran konvensional.

Selain melihat perbedaan hasil belajar antara siswa yang belajar dengan menggunakan model pembelajaran yang berbeda, dalam penelitian ini pun mendeskripsikan perbedaan hasil belajar siswa antara siswa yang mempunyai keterampilan kolaborasi tinggi dengan siswa yang mempunyai keterampilan kolaborasi rendah. Setelah dilakukan pembelajaran dengan menggunakan model project based learning data hasil belajar dianalisis dengan dikelompokkan menjadi dua, yaitu kelompok siswa yang mempunyai keterampilan kolaborasi tinggi dan kelompok siswa yang mempunyai keterampilan kolaborasi rendah. Hasil analisis menunjukkan bahwa secara statistik dengan pengujian anova dua jalur antara siswa yang memiliki keterampilan kolaborasi tinggi dengan siswa yang memiliki keterampilan kolaborasi rendah didapat nilai signifikansi sebesar 0,253 yang mana nilai tersebut lebih besar dari 0,5, itu artinya tidak terdapat perbedaan yang signifikan antara siswa yang mempunyai keterampilan kolaborasi tinggi dengan siswa yang mempunyai keterampilan kolaborasi rendah. Namun data deskriptif menunjukkan nilai rata-rata siswa yang memiliki keterampilan kolaborasi tinggi sebesar 81,2 nilai tersebut lebih tinggi dari pada nilai rata-rata hasil belajar siswa yang mempunyai keterampilan kolaborasi rendah yaitu sebesar 79,2.

Hasil analisis ini ditunjukkan pada Tabel 4.3 di atas. Hal tersebut menunjukkan bahwa hasil belajar peserta didik yang telah diberikan perlakukan dengan project based learning yang disingkat dengan sebesar 83.765. sedangkan hasil belajar peserta didik yang telah diberikan perlakuan dengan model konvensional tanpa video diperoleh nilai sebesar 76.758 .

Hasil yang diperoleh menunjukan arti bahwa hasil belajar peserta didik setelah diberikan perlakuan dengan project based learning lebih besar daripada hasil belajar peserta didik yang diberi perlakukan dengan pembelajaran konvensional. Dalam hal ini terdapat selisih nilai ratarata untuk kedua hasil belajar. Hal ini didukung oleh Wabula yang menyatakan bahwa model project based learning berbantuan video memberikan pengaruh terhadap hasil belajar peserta didik, namun tidak memberi pengaruh terhadap motivasi peserta didik (Wabula, Papilaya, \& Rumahlatu, 2020).

\section{Kesimpulan}

Berdasarkan hasil penelitian dapat disimpulkan bahwa terdapat pengaruh model pembelajaran Project Based Learning terhadap hasil belajar Ilmu Pengetahuan Alam (IPA) peserta didik kelas IV SDN Kecamatan damar. Hasil belajar IPA kelas eksperimen mendapatkan rata-rata sebesar 83,76; nilai terendah sebesar 75; dan nilai tertinggi sebesar 100. Sedangkan kelas kontrol memperoleh rata-rata sebesar 76,75 dengan nilai terendah 45 dan nilai tertinggi 70. Sedangkan rata-rata hasil belajar siswa berdasarkan tingkatan keterampilan kolaborasi yang dimilikinya masih belum menunjukkan perbedaan secara signifikan 
berdasarkan analisis statistik, namun data deskriptif menunjukkan adanya sedikit perbedaan rata-rata antara yang memiliki keterampilan kolaborasi tinggi dengan siswa yang memiliki keterampilan kolaborasi rendah.

Secara garis besar hasil penelitian ini menunjukkan bahwa model pembelajaran project based learning berpengaruh signifikan terhadap hasil belajar IPA. Namun penelitian ini dibatasi pada penggunaan model project based learning pada mata pelajaran IPA di kelas IV SDN Kecamatan Damar, data hasil penelitian dianalisis untuk melihat ada atau tidaknya pengaruh model project based learning terhadap hasil belajar IPA. Dengan demikian perlu dilakukan penelitian lanjutan untuk melihat pengaruh variabel yang sama pada terhadap subjek dan kompetensi yang berbeda agar dapat menambah keluasan khasanah keilmuan yang berkaitan dengan model-model pembelajaran yang efektif digunakan dalam proses pembelajaran.

\section{Daftar Pustaka}

Beers, S. Z. (2011) '21 st Century Skills : Preparing Students for THEIR Future', STEM: Science, Technology, Engineering, Math.

Boss, S., \& Krauss, J. (2013). Thinking Through Project-Based Learning Guiding Deeper Inquiry. United States of America: SAGE Publications.

Creswell. (2014). Research Design. Yogyakarta: Pustaka Pelajar.

Khairudin, \& Soedjono. (2015). Strategi Pembelajaran. Diknas.

Kurniasih. (2014). Implementasi Kurikulum 2013. Surabaya: Kata Pena.

Miharja, U., Rumanta, M, \& Rahayu, U. (2021). Pengaruh Model Inquiry-Based Learning dan Motivasi Belajar terhadap Keterampilan Berpikir Kritis Siswa Kelas V SD. Jurnal Elementaria Edukasia, Vol. 4 No.1, 55 - 64.

Purnomo, H., Mahpudin, \& Sunanto, L. (2020). Pengelolaan Kelas Belajar di Era 4.0. Elementaria Edukasia, 101-108.

Ratumanan. (2015). Inovasi Pembelajaran. Yogyakarta: Penerbit Ombak.

Sudjana, N. (2005). Penilaian Hasil Proses Belajar Mengajar. Jakarta: PT. Remaja Rosdakarya.

Suprihatiningrum, \& Jamil. (2016). Strategi Belajar dan Pembelajaran, Teori \& Aplikasi. Yogyakarta: Ar-Ruzz Media.

Surahman, Paudi, R. I., \& Tureni, D. (2015). Meningkatkan Hasil Belajar Siswa Dalam Pembelajaran IPA Pokok Bahasan Makhluk Hidup dan Proses Kehidupan Melalui Media Gambar Kontekstual Pada Siswa Kelas II SD Alkhairaat Towera. Jurnal Kreatif Tadulako, 91-107.

Susanto. (2012). Teori Belajar dan Pembelajaran di Sekolah Dasar. Jakarta: Kencana Prenada Media Group.

Tias, I. W. (2017). Penerapan Model Penemuan Terbimbing Untuk Meningkatkan Hasil Belajar IPA Siswa Sekolah Dasar. DWIJACENDEKIA Jurnal Riset Pedagogik, 50-60. 
Trianto. (2014). Model Pembelajaran Terpadu. Jakarta: PT Bumi Aksara.

Trilling, B., \& Fadel, C. (2009). 21st Century Skills, Enhanced Edition: Learning for Life in Our Times. John Wiley \& Sons.

Tursinawati. (2013). Analisis Kemunculan Sikap Ilmiah Siswa Dalam Pelaksanaan Percobaan Pada Pembelajaran IPA di SDN Kota Banda Aceh. Jurnal Pionir, 67-84.

Wabula, M., Papilaya, P. M., \& Rumahlatu, D. (2020). Pengaruh Model Pembelajaran Discoveru Learning Berbantuan Video dan Problem Based Learning Terhadap Motivasi dan Hasil Belajar Siswa. Edubiotik: Jurnal Pendidikan, Biologi dan Terapan, 29-41. 